This is the pre-print manuscript of:

Stevo Lavrnić, Xi Nan, Sonia Blasioli, llaria Braschi, Stefano Anconelli, Attilio Toscano

Performance of a full scale constructed wetland as ecological practice for agricultural drainage water treatment in Northern Italy

Ecological Engineering, vol. 154, 2020: 1-10

DOI: https://doi.org/10.1016/j.ecoleng.2020.105927

Rights / License:

The terms and conditions for the reuse of this version of the manuscript are specified in the publishing policy. For all terms of use and more information see the publisher's website. 


\title{
Performance of a full scale constructed wetland as ecological practice for agricultural drainage water treatment in Northern Italy
}

\author{
Stevo Lavrnića ${ }^{*}$, Xi Nan ${ }^{\mathrm{a}}$, Sonia Blasioli ${ }^{\mathrm{a}}$, Ilaria Braschi ${ }^{\mathrm{a}}$, Stefano Anconelli ${ }^{\mathrm{b}}$, Attilio \\ Toscano $^{\mathrm{a}}$
}

${ }^{\text {a }}$ Department of Agricultural and Food Sciences, Alma Mater Studiorum-University of Bologna, Viale Giuseppe Fanin 40-50, 40127 Bologna, Italy; stevo.lavrnic@ unibo.it (S.L.), xi.nan2@unibo.it (X.N.), sonia.blasioli@unibo.it (S.B.), ilaria.braschi@unibo.it (I.B.), attilio.toscano@unibo.it (A.T.)

${ }^{\mathrm{b}}$ Consorzio di Bonifica Canale Emiliano Romagnolo, Via Ernesto Masi 8, 40137 Bologna, Italy; anconelli@ consorziocer.it (S.A.)

* Corresponding author: stevo.lavrnic@unibo.it

\begin{abstract}
Non-point sources of pollution, primarily agricultural drainage waters, can cause eutrophication and deterioration of water bodies. Surface flow constructed wetlands (SFCWs) are an ecological solution that can represent an efficient barrier and prevent agricultural pollutants from reaching other ecosystems. However, to better manage them and to understand removal processes occurring, it is important to study SFCWs that are functioning for longer periods of time and assess their efficiencies. This study concentrates on a full-scale SFCW in the Northern Italy that has been treating agricultural
\end{abstract}


drainage water for past 20 years. An in-deep monitoring done for two years (2018 and 2019) showed that the system achieved satisfactory retention of up to $82 \%$ for TSS and up to $78 \%$ for $\mathrm{TN}$ and $\mathrm{NO}_{3}{ }^{-} \mathrm{N}$. TP retention seemed to be poor, but further analysis showed that the SFCW performed well in this aspect as well, and that it is important to include precipitation loads in the overall balance. Soil content of nutrients and different trace elements did not show considerable differences in respect to the beginning of the monitoring period, and the uptake rates of $\mathrm{TN}$ and $\mathrm{TP}$ by above-ground vegetation were in the range 19.0-26.3 and 1.6-2.1 $\mathrm{g} \mathrm{m}^{-2}$, respectively.

Keywords: nature-based solution; nutrients; surface flow constructed wetland; vegetation

\section{Introduction}

Constructed wetlands (CWs) are generally regarded as an economical, easy operation and effective alternative (Lavrnić and Mancini, 2016; Liu et al. 2015) for treating wastewater of different sources, including domestic and industrial wastewater (Calheiros et al. 2009; Arden and Ma, 2018; Lavrnić et al. 2019; Russo et al. 2019a) and agricultural drainage water (Lavrnić et al. 2018). Reed and cattails are the most common vegetation planted in these ecosystems (Rousseau et al. 2008). The application of CWs can not only reduce pressure on conventional treatment plants (Ghaitidak and Yadav, 2013), but it can also provide habitat for wildlife, aesthetic and recreational values for public (ElZein et al. 2016; Rousseau et al. 2008). Furthermore, treated effluents can be reused for various purposes, such as agricultural irrigation, domestic purposes and gardening (Toscano et al. 2013; ElZein et al. 2016; Dou et al. 2017; Russo et al. 2019b). 
CWs are classified into surface flow constructed wetlands (SFCWs) and subsurface flow ones, based on their hydraulic functioning. The latter one can be further divided into horizontal and vertical flow CWs. In comparison with subsurface systems, SFCWs are the type of $\mathrm{CW}$ that is most commonly used for agricultural drainage water treatment since they provide favourable environment for it (Tanner and Kadlec, 2013; Tournebize et al. 2017; Dal Ferro et al. 2018). SFCW systems are designed using parameters like water depth, size, substrate, plant, etc., and implemented under various requirements (e.g. flow rate, feeding mode) (Headley et al. 2013; Morató et al. 2014; Herrera-Melián et al. 2018; Song et al. 2019). However, factors like seasonal and annual variation, the aging of CW systems or other internal/external conditions have a possibility to negatively affect the treatment performance of CWs, particularly over the longer time periods. Besides, the research on long-term experiments taking into account local conditions is limited in quantity (Dal Ferro et al. 2018).

Agricultural drainage systems shorten the retention time of water in soil, leading to nutrient losses from farmland (Steidl et al. 2019). Agricultural watersheds and their network of ditches and canals may have a high capacity for TN removal due to their heterogeneous hydraulic, ecological and biological parameters (Castaldelli et al. 2018). Nevertheless, the agricultural drainage water can be a source of diffuse pollution in aquatic ecosystems due to high concentrations of nitrate, certain salts, phosphorus, organic nitrogen, pesticides and sediments (Woltemade, 2000; Haverstock et al. 2017), as confirmed by the authors from different parts of the world (Tanner and Kadlec, 2013; Darwiche-Criado et al. 2017; Mendes et al. 2018a; Song et al. 2019). Particularly, P enrichment in runoff leads to eutrophication harmful to plants growth (Johannesson et al. 2017; Lavrnić et al. 2018), and it can even result in toxic algae blooms and loss of 
biodiversity (Reinhardt et al. 2005). Therefore, different international agreements (e.g. European Union Water Framework Directive) were achieved in order to reduce nutrient load from agricultural land and consequently improve water quality in the environment (Ulén et al. 2019).

It was reported that SFCWs can be an inexpensive and efficient nature-based solution for the reduction of non-point source pollution, especially for nitrogen and phosphorus (Tolomio et al. 2019, Pugliese et al. 2020), and they were used for that purpose in different countries (Song et al. 2019). Nitrogen removal/retention in SFCWs mainly depends on the biological and physico-chemical mechanisms (e.g. nitrification/denitrification, plant uptake, biomass assimilation and volatilization) (Billy et al. 2013; Song et al. 2019), while the mechanisms for phosphorus removal include soil accretion, adsorption, microbial/plant uptake and precipitation (Vymazal, 2007). On the other hand, scientific research on the effect that CWs can have on agricultural pollution abatement is still limited, especially the one considering seasonal and long-term hydro-meteorological variations (Ulén et al. 2019). Moreover, since the expansion of SFCWs for agricultural drainage water treatment started a few decades ago (Song et al. 2019), it is important to understand their behaviour and performance once they reach the mature stage.

With these considerations in mind, the present paper studies a full-scale SFCW located in Northern Italy, which was built and is operating since 2000. In the beginning of 2017 the above-ground vegetation was harvested and in-depth monitoring of the system operation started in 2018. After having assessed its historical performance (Lavrnić et al. 2018), the capacity for pesticide removal (Braschi et al. manuscript in preparation) and having evaluated its hydrological and hydraulic behaviour (Lavrnić et al. 2020), the main 
objective of this study was to assess the overall performance for agricultural drainage water treatment of this particular SFCW after two decades of operation.

\section{Materials and methods}

2.1. Experimental set-up and condition of the constructed wetland

The research was conducted at an experimental agricultural farm of Canale Emiliano Romagnolo land reclamation consortium (CER) in the Emilia-Romagna region (Italy), from January 2018 to December 2019. The site has a sub-humid climate, with the mean annual temperature of $13.7^{\circ} \mathrm{C}$ and the average annual rainfall of $771 \mathrm{~mm}$ (Lavrnić et al. 2018). During the monitoring period discussed in this study, the annual climatic conditions were similar to the average, as in 2018 the mean yearly temperature and yearly rainfall were $14.4^{\circ} \mathrm{C}$ and $752 \mathrm{~mm}$, respectively, while in 2019 they were $14.5^{\circ} \mathrm{C}$ and 751 mm, respectively.

The SFCW (Figure 1), constructed in 2000 and operating since, is a part of the experimental farm, occupying about $3 \%$ of the total surface area (12.5 ha) that is inside the recommended range of $0.5-5 \%$ (Tanner and Kadlec, 2013). It has a surface of approximately 0.4 ha and it is an off-stream measure meaning that it is located outside of the main water stream. The farm drainage water flows to the main ditch from where it is abstracted with two pumps and conveyed to the SFCW. The pumps activation depends on the water level inside the ditch. In case it surpasses a certain level, an overflow activates and excess water bypasses the wetland. 

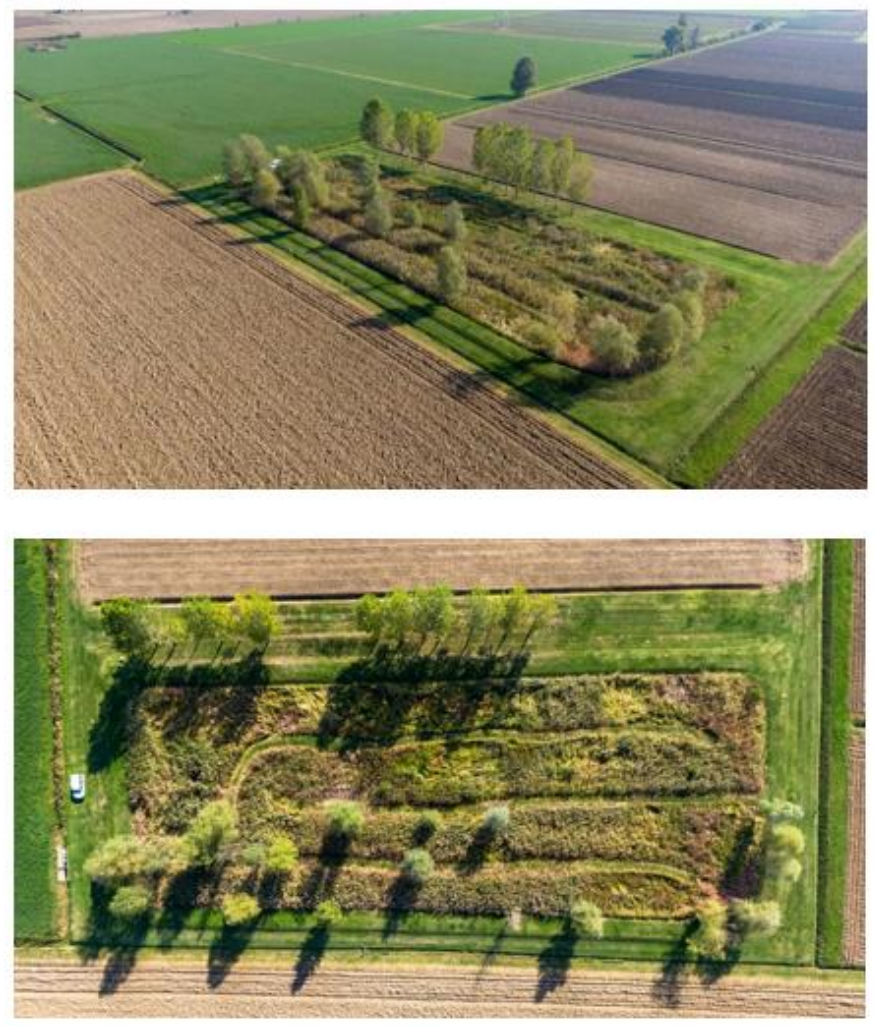

Figure 1 - Areal views and scheme of the monitored SFCW and the surroundings.

The surface of the SFCW was partitioned with a few barriers, effectively dividing it into four 8-10 m wide meanders and creating a $470 \mathrm{~m}$ long water course. The total volume of the system is close to $1,500 \mathrm{~m}^{3}$ and the outlet is set on $0.4 \mathrm{~m}$ above the bed surface level. The most dominant plant species in the SFCW were Phragmites australis, Typha latifolia and Carex spp. Some additional information and the complete description of the experimental system can be found in Lavrnić et al. (2018; 2020).

The system is equipped with two mechanical flow meters that record influent and effluent volumes every hour, and two automatic samplers that take influent and effluent water samples on the basis of the inlet water volume and time, respectively. Since the functioning of the system depends mostly on the presence of precipitation, no general sampling schedule could be established and followed. Hence, due to the lack of drainage water, longer or shorter periods of time passed without sampling. The water level inside 
the $\mathrm{CW}$ is measured by a specific sensor. All the collected data were managed and recorded by a central control system. The precipitation height data were taken from the farm weather station, equipped with a precipitation sampling unit.

\subsection{Water balance}

The hydrological year was considered to begin on $1^{\text {st }}$ January and finish on $31^{\text {st }}$ December. For the analysis purposes, a year was further divided into four seasons: winter (JanuaryMarch), spring (April-June), summer (July-September) and autumn (October-December).

The SFCW dynamic water budget (Kadlec and Wallace, 2009) can be expressed as:

$$
Q_{\text {in }}+(P \times A)-Q_{\text {out }}-I-(E T \times A)=\frac{d V}{d t}
$$

Where:

$Q_{\text {in }}=$ inflow rate $\left(\mathrm{m}^{3} \mathrm{~d}^{-1}\right)$;

$P=$ precipitation rate $\left(\mathrm{m} \mathrm{d}^{-1}\right)$

$A=$ wetland top surface area $\left(\mathrm{m}^{2}\right)$;

$Q_{\text {out }}=$ outflow rate $\left(\mathrm{m}^{3} \mathrm{~d}^{-1}\right)$

$I=$ infiltration flow rate $\left(\mathrm{m}^{3} \mathrm{~d}^{-1}\right)$;

$E T=$ evapotranspiration rate $\left(\mathrm{m} \mathrm{d}^{-1}\right)$;

$V=$ water storage inside the $\mathrm{SFCW}\left(\mathrm{m}^{3}\right)$;

$t=$ time $(\mathrm{d})$ 
Over long averaging periods $(\Delta t)$, the change in storage $(\Delta \mathrm{V})$ can be considered negligible (Kadlec and Wallace, 2009). Even though Lavrnić et al. (2020) had measured punctual infiltration, an overall estimate could not be done. Moreover, it was not possible to measure infiltration and evapotranspiration rates separately. Therefore, a simplified water balance over each hydrological year was calculated as:

$$
Q_{\text {in }}+(P \times A)-Q_{\text {out }}=I+(E T \times A)
$$

In Equation (2), the term $\mathrm{I}+(\mathrm{ET} \times \mathrm{A})$ was considered as the overall water loss from the SFCW, and it represents the water retained by the SFCW, i.e. not released directly to surface water bodies.

Percentage of time that the SFCW was submersed was also estimated, counting the days when the average water level in the system was at least $2 \mathrm{~cm}$. That limit was taken to prevent that measurement errors or accumulation of sediments affect the assessment.

Furthermore, in order to analyse different inflow episodes that occurred during the monitoring period, the data set was divided into periods when influent into the system was continuous. In order to be considered as an inflow event, an episode had to have a permanent inflow for at least 5 consecutive days and a total volume of at least $200 \mathrm{~m}^{3}$. Moreover, to differentiate single events and not confuse them with different parts of the same one, at least 7 consecutive days without inflow before and after the event were taken as a condition. For every inflow event, nominal hydraulic retention time $\left(\mathrm{HRT}_{\mathrm{N}}\right)$ was calculated like in Lavrnić et al. (2020): 


$$
\operatorname{HRT}_{\mathrm{N}}=0.9 * \frac{V}{\frac{Q_{\text {in }}+Q_{\text {out }}}{2}}
$$

\subsection{Water quality}

Water samples (i.e., precipitation and CW influent and effluent) were analysed for chemical oxygen demand (COD), total suspended solids (TSS), total organic carbon (TOC), total nitrogen (TN), nitrate-nitrogen $\left(\mathrm{NO}_{3}{ }^{-}\right)$, ammonium-nitrogen $\left(\mathrm{NH}_{4}{ }^{+}-\mathrm{N}\right)$, nitrite-nitrogen $\left(\mathrm{NO}_{2}^{-}-\mathrm{N}\right)$ and total phosphorus (TP).

COD was analysed spectrophotometrically with a COD Digestion Vials kit (Hach Lange) and TSS by the gravimetric method. TN and TOC were measured by the elemental analyser Shimadzu TNM-1 (Shimadzu, Kioto, Japan). Before analysis, all samples were filtered through Watman 42 filters (Merck KGaA, Darmstadt, Germany). Moreover, $\mathrm{NO}_{2}^{-}, \mathrm{NO}_{3}{ }^{-}$and $\mathrm{NH}_{4}{ }^{+}$concentrations were determined by using a flow analyser (AA3, Bran Luebbe, Norderstedt, Germany). TP analysis was performed by using an inductively coupled plasma optical emission spectrometer ICP-OES which was equipped with a plasma source and an optical detector with a charge-coupled device CCD (SPECTRO Analytical Instruments GmbH \& Co., Kleve, Germany). Before analysis, in filtered water samples was added $1 \%$ of $\mathrm{HNO}_{3}(>69 \%$ v/v, for trace analysis, Fluka, Sigma-Aldrich, St. Louis, MO, USA).

The concentration of different parameters in influent $\left(\mathrm{C}_{\text {in }}, \mathrm{mg} \cdot \mathrm{L}^{-1}\right)$ and effluent $\left(\mathrm{C}_{\text {out }}\right.$, $\left.\mathrm{mg} \cdot \mathrm{L}^{-1}\right)$ were multiplied by the corresponding water volume that flowed into $\left(\mathrm{V}_{\text {in }}, \mathrm{m}^{3}\right)$ or out $\left(\mathrm{V}_{\text {out }}, \mathrm{m}^{3}\right)$ of the system, respectively. Afterwards, all the inflow and outflow loads during one hydrological year/inflow event were summed to calculate the mass of nutrients 
$\left(\mathrm{kg} \mathrm{year}^{-1}\right)$ entering and exiting the wetland. In general, mass load retention rate $(R R, \%)$ during each period of time, was calculated as:

$$
R R=\frac{\sum V_{\text {in }} \times C_{\text {in }}-\sum V_{\text {out }} \times C_{\text {out }}}{\sum V_{\text {in }} \times C_{\text {in }}} \times 100
$$

\subsection{Soil}

At the end of the monitoring period, in November 2019, the soil was sampled at four points along the water course (at the middle of each meander) in order to allow comparison with results from 2017 (Lavrnić et al. 2018), that were taken as a background condition for the present study. At each position, $60 \mathrm{~cm}$ soil core samples were taken. First $5 \mathrm{~cm}$ were removed from the sample since they were mostly made of litter and mud, and therefore they were not representative of the real composition of the SFCW soil layer. After manual removal of plant roots up to a diameter of ca. 1-2 mm, the samples were air-dried and sieved to $2 \mathrm{~mm}$. Afterwards, they were tested for TP and trace elements content, using the methods given in section 2.4 , as well as for TOC and TN.

TOC and TN in the soil samples were determined by using a thermo-electron CHNS-O elemental analyser (Thermo Fisher Scientific, Waltham, MA, USA). TP and metal concentrations were analysed by using ICP-OES, after dissolution of soil samples in a mixture of $\mathrm{HCl}\left(37 \% v / v\right.$ for trace analysis, Sigma-Aldrich, St. Louis, MO, USA), $\mathrm{HNO}_{3}$ (>69\% v/v, for trace analysis, Fluka, Sigma-Aldrich, St. Louis, MO, USA), and $\mathrm{H}_{2} \mathrm{O}_{2}$ ( $30 \% v / v$, for trace analysis, VWR Prolabo Chemicals, Radnor, PA, USA) in the ratio of 4:1:0.25 (v:v:v) by microwave-assisted digestion (Start D, Micro-wave Digestion System, Milestone, MD, USA). 


\subsection{Vegetation}

The plants were sampled in a representative $1 \mathrm{~m}^{2}$ area at the middle of each of the four meanders, once a year (end of October or beginning of November). They were tested and analysed for nutrient and trace elements content.

Biomass dry weight and average height were measured. Additionally, biomass samples were divided into below- and above-ground biomass, and were tested for TOC, TN and TP content, as well as for the presence of the semi-metal B and different heavy metals $(\mathrm{Cd}, \mathrm{Cr}, \mathrm{Cu}, \mathrm{Fe}, \mathrm{Pb}, \mathrm{Mn}, \mathrm{Ni}$ and $\mathrm{Zn})$.

TN and TOC analysis of vegetation was performed by using a thermo-electron CHNS-O elemental analyser (Thermo Fisher Scientific, Waltham, MA, USA). TP and trace elements were measured using ICP-OES. Before elemental analysis, biomass samples were dissolved in a mixture of $\mathrm{HNO}_{3}(>69 \%$ v/v, for trace analysis, Fluka, Sigma-Aldrich, St. Louis, MO, USA) and $\mathrm{H}_{2} \mathrm{O}_{2}(30 \% v / v$, for trace analysis, VWR Prolabo Chemicals, Radnor, PA, USA) in the ratio of $4: 1(v: v)$ by microwave-assisted digestion (Start D, Micro-wave Digestion System, Milestone srl, Bergamo, Italy).

3. Results and discussion

\subsection{Simplified overall water balance}

The irregular hydrological nature of the system can be best seen through inflow (considering the direct precipitation onto the system) and outflow volume comparison (Table 1). It is important to note that the inflow is originally rainwater, since the farm uses a modern irrigation system that applies water in quantities that are necessary to maintain the soil humidity at a certain level. The major inflow, and consequently outflow, in the system occurred during the two 2018 winter months (February and March), with 
values that were several times higher comparing to the rest of the period considered. The inflow to the SFCW, together with outflow, varied considerably throughout the monitoring period since it depended on the presence of precipitation, but it was also strongly connected to season, temperature and crop water needs.

Table 1 - Seasonal hydrology of the monitored SFCW.

\begin{tabular}{|c|c|c|c|c|c|c|}
\hline Season & $\begin{array}{c}\text { Inflow } \\
\left(\mathrm{m}^{3}\right)\end{array}$ & $\begin{array}{c}\text { Outflow } \\
\left(\mathrm{m}^{3}\right)\end{array}$ & $\begin{array}{l}\text { Submersion } \\
\text { (\% of time) }\end{array}$ & $\begin{array}{c}\text { Water } \\
\text { retention/loss } \\
(\%)\end{array}$ & $\begin{array}{c}\text { Mean air } \\
\text { temperature } \\
\left({ }^{\circ} \mathrm{C}\right)\end{array}$ & $\begin{array}{c}\text { Seasonal } \\
\text { precipitation } \\
(\mathrm{mm})\end{array}$ \\
\hline Winter 2018 & 17,102 & 12,294 & 100 & 28 & 5.1 & 261 \\
\hline Spring 2018 & 2,584 & 0 & 95 & 100 & 18.7 & 190 \\
\hline $\begin{array}{l}\text { Summer } \\
2018\end{array}$ & 1,904 & 0 & 32 & 100 & 24.0 & 155 \\
\hline $\begin{array}{l}\text { Autumn } \\
2018\end{array}$ & 799 & 0 & 0 & 100 & 10.0 & 147 \\
\hline Winter 2019 & 1,036 & 0 & 44 & 100 & 5.7 & 69 \\
\hline Spring 2019 & 1,646 & 0 & 31 & 100 & 17.2 & 229 \\
\hline $\begin{array}{l}\text { Summer } \\
2019\end{array}$ & 614 & 0 & 0 & 100 & 23.5 & 155 \\
\hline $\begin{array}{l}\text { Autumn } \\
2019\end{array}$ & 6,688 & 1,944 & 49 & 71 & 11.2 & 199 \\
\hline $\begin{array}{l}\text { Overall } \\
\text { period }\end{array}$ & 26,847 & 14,265 & 44 & 56 & - & 1,504 \\
\hline
\end{tabular}

For example, in 2018, the overall inflow (including the direct precipitation input) and outflow were $22,389 \mathrm{~m}^{3}$ and $12,294 \mathrm{~m}^{3}$, respectively, while in 2019 those values were much lower - 9,983 $\mathrm{m}^{3}$ and $1,944 \mathrm{~m}^{3}$, respectively (Table 1 ). Like other types of naturebased solutions, SFCWs used for agricultural drainage water treatment are being used at different scales, for different catchments and in different climates, and that makes comparison among them rather difficult. In this study, the average water inflow $\left(61 \mathrm{~m}^{3}\right.$ day $^{-1}$ in 2018 and $27 \mathrm{~m}^{3}$ day $^{-1}$ in 2019) was much lower than the one given by Dal Ferro et al. (2018) for a SFCW in the Veneto region (Italy) that approximately amounted to 5,480 $\mathrm{m}^{3}$ day $^{-1}$, but was also much higher than $17 \mathrm{~m}^{3}$ day ${ }^{-1}$ for a Canadian SFCW studied by Haverstock et al. (2017). 
In 2018 and 2019, water retention/loss, the difference between inflow and outflow, were $45 \%$ and $81 \%$, respectively. Considering the whole monitoring period, the loss was higher than $55 \%$ (Table 1), and, apart from evapotranspiration and accumulation in the system itself, the important part of it was infiltration into the ground, as concluded by a previous study done on the same SFCW (Lavrnić et al. 2020). Actually, the authors presume that the biggest part of the water loss was exactly due to infiltration processes. For example, during the winter period 2018, when the temperatures were quite low and the vegetation was in senescence (with minimal evapotranspiration), water retention/loss was $28 \%$ (Table 1), indicating that most of it infiltrated to the ground. Similar conclusion could be taken also when analysing winter 2019. In addition, similar results were given by Kovacic et al. (2006), who stated that evapotranspiration represented 8-29\% of the total water loss for two SFCW treating agricultural drainage water in USA, while the rest was infiltration.

If the SFCW seasonal hydrology is analysed, it can be noted that the biggest part (53\%) of the two-year inflow into the system occurred during one single season (winter 2018). The inflow during the 18 months period between spring 2018 and summer $2019(8,582$ $\mathrm{m}^{3}$ ) was comparable to the autumn 2019 inflow $\left(6,688 \mathrm{~m}^{3}\right.$ ) (Table 1), even more highlighting the hydrological unpredictability of the SFCW discussed. The system was able to accumulate to a large extent the small inflows that occurred between spring 2018 and summer 2019 owing to its total volume of about 1,500 $\mathrm{m}^{3}$. Aided by other types of water loss, it limited or completely eliminated outflow. Similar conditions and occasional dry out of a SFCW was also reported by Ulén et al. (2019). However, that study, done in Sweden, did not report $100 \%$ water losses for either of the 8 seasons considered, probably because the SFCW represented only $0.3 \%$ of the contributing catchment (compared to $3 \%$ in this study) and therefore it had a rather high inflow of water. 
The smallest water retention/loss occurred during winter 2018, mostly due to the high water inflow and consequently high water level that reduced HRT. In SFCWs that are receiving fluctuating inflow, it is important to consider the percentage of time during which the system is submersed, or, in other words, when the bottom is covered with water. The submersion period was a difficult parameter to estimate since it would often happen that water is present only near the inlet while the second part of the system is dry. For example, dry periods were certainly autumn 2018 and summer 2019, when the inflow was small and dispersed throughout the season. In those conditions, inflow was never large enough to reach the outflow part and, therefore, to submerge the whole system. On the other hand, in winter 2018, as already mentioned, the SFCW received a high inflow and the system was submersed all the time (Table 1).

\subsection{Hydrological analysis of single inflow events}

Table 2 gives characteristics of single inflow events that occurred during the monitoring period. Comparable intensive rain episodes occurred in May-July 2018 (Event 2, Table 2) and in November-December 2019 (Event 7, Table 2), but they did not cause a similar response in water flow. The reason can be found in the atmospheric conditions during these two events.

In particular, the Event 7 occurred in winter time, when the vegetation was in senescence and the average daily temperature was $7.2^{\circ} \mathrm{C}$, that for a few days was even below $1{ }^{\circ} \mathrm{C}$. Those conditions minimised evapotranspiration from the agricultural fields, caused a faster runoff from the farm area and increased water inflow to the SFCW. On the contrary, Event 2 occurred during the growth phase of the farm crops and when the average 
temperature was $23.1^{\circ} \mathrm{C}$. Therefore, it can be assumed that crop water needs and evapotranspiration caused a much smaller water flow.

The Events 3 and 5 were events with a much smaller intensity and consequently they did not produce high inflow. However, the Event 6, although it was a result of three times bigger rain episode, produced a similar inflow as the Event 4. The answer can be again found in the overall conditions. After August, most of the crops grown at the CER farm area are harvested and the bare soil certainly facilitates runoff. On the other hand, spring period is when crops are growing and require constant humidity and therefore, similarly to the Event 2, they could have retained most of the precipitation that occurred in April and May 2019.

Table 2 - Single inflow events during the two-year long monitoring period.

\begin{tabular}{llccccccc}
\hline Event & Period & $\begin{array}{c}\text { Duration } \\
(\mathrm{d})\end{array}$ & $\begin{array}{c}\text { Inflow } \\
\left(\mathrm{m}^{3}\right)\end{array}$ & $\begin{array}{c}\text { Outflow } \\
\left(\mathrm{m}^{3}\right)\end{array}$ & $\begin{array}{c}\text { Initial } \\
\text { water } \\
\text { level }(\mathrm{cm})\end{array}$ & $\begin{array}{c}\text { HRT } \\
(\mathrm{d})\end{array}$ & $\begin{array}{c}\text { Precipitation } \\
(\mathrm{mm})\end{array}$ & $\begin{array}{c}\text { Temperature } \\
\left({ }^{\circ} \mathrm{C}\right)\end{array}$ \\
\hline 1 & $\begin{array}{l}\text { Feb-Apr } \\
2018\end{array}$ & 82 & 17,373 & 12,296 & 7.0 & 6.6 & 264 & 7.8 \\
2 & $\begin{array}{l}\text { May-Jul } \\
2018\end{array}$ & 59 & 2,425 & 0 & 0.6 & - & 204 & 23.1 \\
3 & Aug 2018 & 8 & 283 & 0 & 1.6 & - & 11 & 25.6 \\
4 & $\begin{array}{l}\text { Sep-Oct } \\
2018\end{array}$ & 36 & 1,227 & 0 & 1.5 & - & 55 & 19.5 \\
5 & $\begin{array}{l}\text { Feb 2019 } \\
5\end{array}$ & 7 & 930 & 0 & 0.7 & - & 44 & 3.3 \\
7 & $\begin{array}{l}\text { Apr-May } \\
2019\end{array}$ & 34 & 1,179 & 0 & 0.2 & - & 158 & 14.6 \\
\hline
\end{tabular}

The elevated flows that occurred between February and April 2018 (Event 1, Table 2) are, as already said, a result of precipitation that was really high during that period (264 mm). An inflow event such as the Event 1 has never been recorded since 2000, the year when the SFCW started functioning. It can be seen that inflow into the system and its frequency depended on the presence and intensity of rain. The inflow affected water level 
inside the SFCW, that in turn, regulated the outflow (Figure 2). The most intensive rainfall occurred during the first 3 weeks (until the $23^{\text {rd }}$ of February) and again in the period $5^{\text {th }}$ $11^{\text {th }}$ of March, and it certainly reflected on the influent pattern. The most important outflow happened until the $25^{\text {th }}$ of March, and after that date it slowed down due to the absence of intensive rainfall. Although the inflow activity continued beyond that date, its average value was $15 \mathrm{~m}^{3} \mathrm{~d}^{-1}$ and therefore it did not produce substantial response in terms of outflow or water level increase.

Only two out of the identified seven single events had a considerable outflow and therefore it was possible to calculate their HRT. Nevertheless, it is an important parameter that sheds more light onto the processes occurring inside the system and leading to the retention of pollutants (Song et al. 2019; Pugliese et al. 2020). For example, it has been suggested that the minimum HRT needed for TN reduction on a catchment scale is 2 days (Song et al. 2019). All the events considered in this study had a much higher HRT than that limit, most probably contributing to the substantial $\mathrm{TN}$ retention that will be discussed in the next section. In order for HRT to be lower than 2 days, the average daily flow of the SFCW studied would have to be higher than $680 \mathrm{~m}^{3} \mathrm{~d}^{-1}$ for at least 2 days. However, none of the inflow events that occurred in 2018 and 2019 reached that limit, and the maximum daily flow recorded was $618 \mathrm{~m}^{3} \mathrm{~d}^{-1}$. 

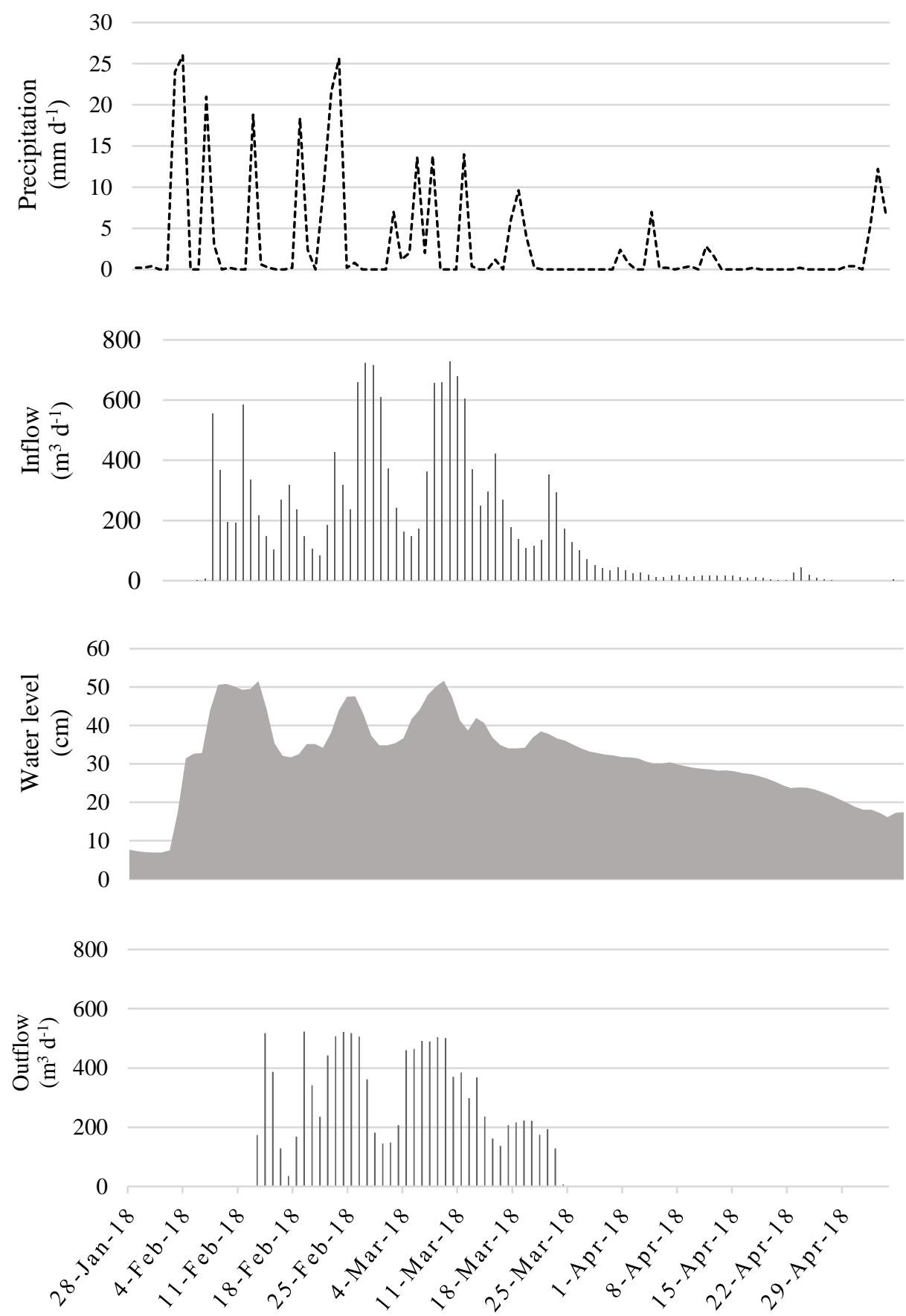

Figure 2 - Hydrological conditions during the Event 1 (Feb-Apr 2018).

\subsection{Water quality}

The mean concentrations and mass loads of different parameters in influent and effluent water of the SFCW monitored can be found in Table 3. The similar concentrations in influent and effluent are a consequence of the relatively high water retention/loss (Table 
1). In general, the system achieved satisfactory overall retention of pollutants. Inflow events with no outflow have certainly had an important contribution since the whole pollution load remained inside the SFCW. A part of it was infiltrated and reached surface water bodies via ground water. However, during the percolation process the pollution load has undoubtedly undergone additional treatment (Bali et al. 2010), and thus the SFCW provided an additional positive effect.

TSS was the parameter with the highest incoming load to the SFCW. Yearly TSS load in the SFCW was 2,622 and $949 \mathrm{~kg}$ in 2018 and 2019, respectively. If divided by the surface area of the contributing catchment, the load was in the range $75-210 \mathrm{~kg} \mathrm{ha}^{-2}$. These values were lower than the ones reported by Ulén et al. (2019) for a SFCW in Sweden, probably due to the different type of catchment. However, in this study, TSS retention was satisfactory: 65 and $82 \%$ in 2018 and 2019, respectively.

Agricultural drainage waters usually do not contain elevated concentrations of organics (Vymazal and Dvořáková Březinová, 2018a) but they can still contribute to eutrophication and dissolved oxygen depletion (He et al. 2011). Average COD influent concentration was $24.3 \mathrm{mg} \mathrm{L}^{-1}$, with minimum and maximum value of $0.0 \mathrm{mg} \mathrm{L}^{-1}$ and $113.0 \mathrm{mg} \mathrm{L}^{-1}$. The effluent one was slightly lower (23.7 $\mathrm{mg} \mathrm{L}^{-1}$, Table 3). However, the system managed to remove $347 \mathrm{~kg}$ of COD over two years of monitoring, or $779 \mathrm{~kg}$ COD ha $^{-1}$ year $^{-1}$ in 2018 and $230 \mathrm{~kg} \mathrm{COD} \mathrm{ha}^{-1} \mathrm{year}^{-1}$ in 2019. This retention was comparable to $287 \mathrm{~kg} \mathrm{COD} \mathrm{ha}^{-1}$ year $^{-1}$ reported by Maniquiz et al. (2012) for a SFCW in South Korea. 
Table 3 - Average concentrations (mean \pm std. error (sample size)) and mass loads of the water quality parameters during the monitoring period (2018-2019).

\begin{tabular}{|c|c|c|c|c|c|c|}
\hline & & \multicolumn{2}{|c|}{ Influent } & \multicolumn{2}{|c|}{ Effluent } & \multirow{2}{*}{$\begin{array}{c}\text { Retention } \\
\text { Mass } \\
\text { load } \\
(\%) \\
\end{array}$} \\
\hline & & $\begin{array}{l}\text { Concentration } \\
\quad\left(\mathrm{mg} \mathrm{L}^{-1}\right)\end{array}$ & $\begin{array}{l}\text { Mass } \\
\text { load } \\
(\mathrm{kg})\end{array}$ & $\begin{array}{l}\text { Concentration } \\
\left(\mathrm{mg} \mathrm{L}^{-1}\right)\end{array}$ & $\begin{array}{l}\text { Mass } \\
\text { load } \\
(\mathrm{kg})\end{array}$ & \\
\hline \multirow[t]{3}{*}{ COD } & Overall & $24.3 \pm 28.6(20)$ & 622 & $23.7 \pm 9.3(11)$ & 304 & 51 \\
\hline & 2018 & $26.8 \pm 34.2(14)$ & 495 & $18.5 \pm 9.3(6)$ & 227 & 54 \\
\hline & 2019 & $18.7 \pm 3.4(6)$ & 139 & $29.9 \pm 4.5(5)$ & 60 & 57 \\
\hline \multirow[t]{3}{*}{ TOC } & Overall & $8.0 \pm 3.0(49)$ & 197 & $10.4 \pm 2.7(28)$ & 135 & 33 \\
\hline & 2018 & $8.0 \pm 2.1(26)$ & 148 & $10.1 \pm 1.8(20)$ & 116 & 21 \\
\hline & 2019 & $7.9 \pm 3.9(23)$ & 48 & $11.0 \pm 4.2(8)$ & 19 & 62 \\
\hline \multirow[t]{3}{*}{ TSS } & Overall & $\begin{array}{c}162.4 \pm 172.3 \\
(76)\end{array}$ & 3,579 & $\begin{array}{c}78.0 \pm 35.2 \\
(30)\end{array}$ & 1,101 & 69 \\
\hline & 2018 & $\begin{array}{c}186.4 \pm 218.9 \\
(42)\end{array}$ & 2,622 & $\begin{array}{c}76.9 \pm 33.5 \\
(22)\end{array}$ & 928 & 65 \\
\hline & 2019 & $132.7 \pm 79.2(34)$ & 949 & $80.7 \pm 42.0(8)$ & 173 & 82 \\
\hline \multirow[t]{3}{*}{$\mathrm{TN}$} & Overall & $12.6 \pm 7.9(76)$ & 428 & $12.3 \pm 4.9(30)$ & 204 & 52 \\
\hline & 2018 & $11.4 \pm 6.4(42)$ & 289 & $11.8 \pm 4.4(22)$ & 174 & 40 \\
\hline & 2019 & $14.1 \pm 9.3(34)$ & 138 & $13.8 \pm 6.3(8)$ & 30 & 78 \\
\hline \multirow[t]{3}{*}{$\mathrm{NH}_{4}{ }^{+}-\mathrm{N}$} & Overall & $0.43 \pm 0.57(60)$ & 5.3 & $\begin{array}{c}0.10 \pm 0.30 \\
\quad(22)\end{array}$ & 1.8 & 66 \\
\hline & 2018 & $0.44 \pm 0.61(42)$ & 2.5 & $\begin{array}{c}0.10 \pm 0.31 \\
(19)\end{array}$ & 1.6 & 35 \\
\hline & 2019 & $0.40 \pm 0.46(18)$ & 2.6 & $0.09 \pm 0.15(3)$ & 0.2 & 91 \\
\hline \multirow[t]{3}{*}{$\mathrm{NO}_{3}-\mathrm{N}$} & Overall & $9.1 \pm 6.5(76)$ & 326 & $9.1 \pm 4.2(30)$ & 155 & 52 \\
\hline & 2018 & $8.4 \pm 5.5(42)$ & 221 & $8.7 \pm 3.7(22)$ & 132 & 40 \\
\hline & 2019 & $10.0 \pm 7.8(34)$ & 105 & $10.4 \pm 5.4(8)$ & 23 & 78 \\
\hline \multirow[t]{3}{*}{$\mathrm{NO}_{2}^{-}-\mathrm{N}$} & Overall & $0.05 \pm 0.08(40)$ & 1 & $\begin{array}{c}0.13 \pm 0.12 \\
\quad(22)\end{array}$ & 1.8 & - \\
\hline & 2018 & $0.04 \pm 0.08$ & 0.5 & $\begin{array}{l}0.13 \pm 0.12 \\
(19)\end{array}$ & 1.6 & - \\
\hline & 2019 & $0.06 \pm 0.09(5)$ & 0.5 & $0.11 \pm 0.14(3)$ & 0.2 & 29 \\
\hline \multirow[t]{3}{*}{ TP } & Overall & $0.05 \pm 0.14(76)$ & 0.5 & $\begin{array}{c}0.02 \pm 0.09 \\
(30)\end{array}$ & 0.6 & - \\
\hline & 2018 & $0.05 \pm 0.12(42)$ & 0.4 & $\begin{array}{l}0.03 \pm 0.10 \\
(22)\end{array}$ & 0.6 & - \\
\hline & 2019 & $0.06 \pm 0.15$ & 0.1 & $0.01 \pm 0.01(8)$ & 0.0 & 100 \\
\hline
\end{tabular}


The average concentration of TOC increased from $8.0 \mathrm{mg} \mathrm{L}^{-1}$ in influent to $10.4 \mathrm{mg} \mathrm{L}^{-1}$ in effluent. On the other hand, the mass load retention of this element was $21 \%$ and $62 \%$ in 2018 and 2019, respectively. That was better performance than $2-17 \%$ range that was found by Kovacic et al. (2006) for two SFCWs treating agricultural drainage water in USA.

The average TN influent concentration was $12.6 \mathrm{mg} \mathrm{L}^{-1}$, with the maximum and minimum value of $37.9 \mathrm{mg} \mathrm{L}^{-1}$ and $1.4 \mathrm{mg} \mathrm{L}^{-1} . \mathrm{NO}_{3}^{-}-\mathrm{N}$ is usually the biggest component of TN in agricultural drainage water (Borin and Tocchetto, 2007; Song et al. 2019), and it was also the case in this study where its load represented more than $75 \%$ of TN entering the SFCW (Table 3). The average influent concentration of $\mathrm{NO}_{3}{ }^{-}-\mathrm{N}$ was $9.1 \mathrm{mg} \mathrm{L}^{-1}$, but, similar to other parameters, it fluctuated a lot in the range $0.3-24.1 \mathrm{mg} \mathrm{L}^{-1}$. Similar finding was reported by Tanner and Kadlec (2013) who stated that nitrate concentrations often vary between events, seasons and locations.

$\mathrm{NO}_{3}^{-}-\mathrm{N}$ influent concentration was higher, but in line with the one reported by Haverstock et al. (2017) $\left(6.7 \mathrm{mg} \mathrm{L}^{-1}\right)$, who also reported a much smaller effluent concentration $(2.2$ $\mathrm{mg} \mathrm{L}^{-1}$ vs $9.1 \mathrm{mg} \mathrm{L}^{-1}$ in this study). A likely reason for such difference is that Haverstock et al. studied a waterproofed SFCW, that did not lose water to seepage, and to the fact that it was located in Canada, in a colder climatic zone where evapotranspiration was not that high. Therefore, their effluent was not as concentrated as the one presented in this study.

Moreover, the nutrient concentrations were much higher than those reported by Dal Ferro et al. (2018) for a SFCW also located in the Northern Italy, with a much bigger catchment area. There, due to the complexity of its drainage network, considerable part of TN and 
its components could have been removed (Castaldelli et al. 2018) before reaching the SFCW. On the other hand, in this study, the CER experimental farm is small and its drainage water collection ditch is no longer than $500 \mathrm{~m}$, thus lower capacity for nutrient retention.

Both $\mathrm{TN}$ and $\mathrm{NO}_{3}{ }^{-}-\mathrm{N}$ retention over the two-year period was $52 \%$ (Table 2). If single years are analysed, the retention was only $40 \%$ in 2018 . This value was lower than $68 \%$ reported by Haverstock et al. (2017), most probably due to the lower HRT. In fact, the average HRT during the Event 1, that represented $76 \%$ of the total yearly inflow, was 6.6 days (Table 3), while for the system studied by Haverstock et al. it was 15 days. Moreover, wetlands that receive steady flows of diffuse nitrate-rich run-off can achieve higher removals than those with pulse and inconsistent inflows (Tanner and Kadlec, 2013), such as the SFCW reported in this study. In 2019, the second year of monitoring, with a much lower inflow and consequently longer HRT than in $2018, \mathrm{TN}$ and $\mathrm{NO}_{3}{ }^{-} \mathrm{N}$ retention was almost $80 \%$. For example, the Event 7 accounted for $75 \%$ of the 2019 total inflow and had a HRT of 11.6 days.

The retention of TN mass load in 2018 was higher than in 2019, likely as a result of a much higher influent load of TN (Table 3). Expressed in surface terms, the SFCW retained $334 \mathrm{~kg} \mathrm{TN} \mathrm{ha}^{-1}$ year $^{-1}$ in 2018 and $314 \mathrm{TN} \mathrm{ha}^{-1}$ year $^{-1}$ in 2019. This is in line with Vymazal (2017) who found a median retention of $426 \mathrm{~kg} \mathrm{TN} \mathrm{ha}^{-1}$ year $^{-1}$ for $41 \mathrm{CWs}$ treating agricultural drainage water.

Influent TP concentration $\left(0.05 \mathrm{mg} \mathrm{L}^{-1}\right)$ was in line, but generally lower than those given by Johannesson et al. (2017) for several Swedish SFCWs treating runoff from arable land. Effluent concentration was slightly lower $\left(0.02 \mathrm{mg} \mathrm{L}^{-1}\right)$, but the load of this nutrient in 
the outlet was higher than in the inlet (Table 2). Since phosphorus removal occurs mainly by physical settling (Tanner and Kadlec, 2013), its negative removal, or, in other words, highest effluent than influent load, can be explained by flush out of sediments containing this element during a high flow event (Kynkaanniemi.et al. 2013). Moreover, the excess phosphorus might be a consequence of the vegetation decay and translocation and algal and microbial activity (Dal Ferro et al. 2018; Mendes et al. 2018b).

\subsubsection{Retention efficiency during the Event 1 (Feb-Apr 2018)}

Influent and effluent concentration trends for selected parameters during the Event 1 are given in Figure 3. Influent concentration is generally higher than the effluent one, but they both followed a similar pattern. The average TSS, TN and $\mathrm{NO}_{3}{ }^{-}-\mathrm{N}$ influent concentration was $111.0,15.6$ and $12.0 \mathrm{mg} \mathrm{L}^{-1}$, respectively, while for effluent they were 73.2, 12.5 and $9.3 \mathrm{mg} \mathrm{L}^{-1}$, respectively (Figure 3).

Being such a high inflow event that occurred in relatively short time ( 82 days), it is especially interesting to see how the SFCW reacted to the increased influent load and how it performed under constant stress. The retention efficiencies were generally lower comparing to the whole monitoring period (Table 4). Especially low retention of TOC (10\%) was recorded, together with a negative retention of $\mathrm{NH}_{4}{ }^{+}-\mathrm{N}, \mathrm{NO}_{2}{ }^{-}-\mathrm{N}$ and TP. That was probably caused by the fact that the Event 1 mostly happened during the winter season when low temperatures do not favour removal/retention processes. Moreover, the big flow of water inevitably lowered HRT in the system and therefore further reduced its treatment capacity. However, one of the main reasons could be the presence of litter from the previous year. The above-ground vegetation usually starts its senescence in November and by February, when the Event 1 started, plant residue decomposition provides 
additional organic material on the bed surface. Therefore, although the litter/decomposition effect cannot be quantified, it might be considered as an additional load and pressure on the system during this specific inflow event.

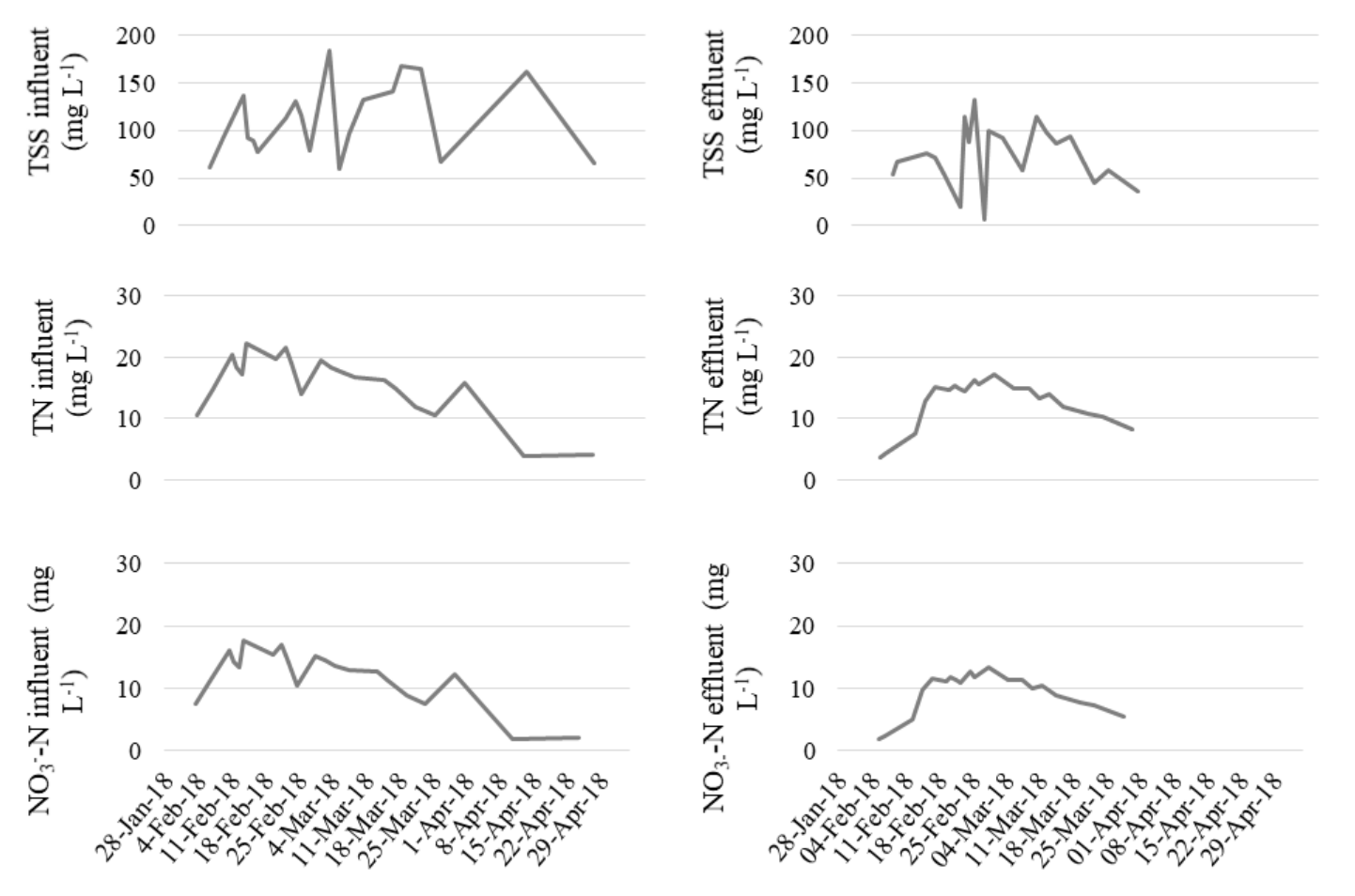

Figure 3 - Influent and effluent concentrations of total suspended solids (TSS), total nitrogen $(\mathrm{TN})$ and nitrate-nitrogen $\left(\mathrm{NO}_{3}{ }^{-} \mathrm{N}\right)$ during the Event 1 (Feb-Apr 2018)

Table 4 - Retention rates during the Event 1 (Feb-Apr 2018).

\begin{tabular}{lccc}
\hline & $\begin{array}{c}\text { Inflow load } \\
(\mathrm{kg})\end{array}$ & $\begin{array}{c}\text { Outflow load } \\
(\mathrm{kg})\end{array}$ & $\begin{array}{c}\text { Retention } \\
(\%)\end{array}$ \\
\hline $\mathrm{COD}$ & 418.3 & 226.7 & 46 \\
$\mathrm{TOC}$ & 129.7 & 116.4 & 10 \\
$\mathrm{TSS}$ & $2,030.4$ & 926.7 & 54 \\
$\mathrm{TN}$ & 275.5 & 173.6 & 37 \\
$\mathrm{NH}_{4}{ }^{+}-\mathrm{N}$ & 1.12 & 1.59 & - \\
$\mathrm{NO}_{3}{ }^{-}-\mathrm{N}$ & 213.3 & 131.8 & 38 \\
$\mathrm{NO}_{2}{ }^{-}-\mathrm{N}$ & 1.08 & 1.58 & - \\
$\mathrm{TP}^{-}$ & 0.3 & 0.62 & - \\
\hline
\end{tabular}




\subsubsection{Nutrient input through precipitation}

TP retention in other SFCWs treating agricultural drainage water was higher than in the present study. For example, Ulén et al. (2019) reported TP retention between 16 and 56\% for a SFCW in Sweeden, while Dal Ferro et al. (2018) concluded that a SFCW in the Italian region of Veneto removed $38 \%$ of influent $\mathrm{PO}_{4}-\mathrm{P}$ load. Although examples of negative retention of TP or its components were recorded (Kynkaanniemi et al. 2013; Dal Ferro et al. 2018), the authors of this study were intrigued that neither of the two years considered had a positive TP retention, while historical monitoring data of the same SFCW (Lavrnić et al. 2018), where nutrient atmospheric input has been included, showed that the system was able to remove TP.

Nutrients are present in rainwater in different concentrations (Vant and Gibbs, 2006, Hoffman et al. 2019), but their input through rainfall is usually not considered in the overall balance. However, it could represent a considerable input when nutrient load through influent is small, as is the case with TP in this study. Therefore, it was decided to monitor also rainwater quality during one inflow event (Event 6) and compare the precipitation and inflow nutrient loads to SCFW. Table 5 reports the concentration and load of nitrogen and its forms as well as phosphorus in both influent and rainwater.

The data suggest that, although $\mathrm{NO}_{3}{ }^{-}-\mathrm{N}$ input through precipitation might be insignificant, rainwater load can represent an important component of the overall balance of $\mathrm{TN}$ and especially for $\mathrm{NH}_{4}{ }^{+}-\mathrm{N}$ and TP. In fact, if precipitation is not considered in the overall balance, the retention of TP by the SFCW might seem negative (Table 3). However, when input by precipitation during only one inflow event is taken into account, the situation 
can change significantly, increasing TP input by about $25 \%$ and consequently changing TP retention from negative to positive.

Table 5 - Comparison of nutrient input through influent and precipitation in the Event 6 (Apr-May 2019).

\begin{tabular}{llcc}
\hline & & Influent & Precipitation \\
\hline $\mathrm{TN}$ & Concentration $\left(\mathrm{mg} \mathrm{L}^{-1}\right)$ & 22.09 & 5.01 \\
& Load $(\mathrm{kg})$ & 14.55 & 2.44 \\
$\mathrm{NO}_{3}{ }^{-} \mathrm{N}$ & Concentration $\left(\mathrm{mg} \mathrm{L}^{-1}\right)$ & 14.67 & 0.54 \\
& Load $(\mathrm{kg})$ & 10.11 & 0.28 \\
$\mathrm{NH}_{4}{ }^{+}-\mathrm{N}$ & Concentration $\left(\mathrm{mg} \mathrm{L}^{-1}\right)$ & 0.34 & 2.09 \\
& Load $(\mathrm{kg})$ & 0.10 & 1.03 \\
$\mathrm{TP}$ & Concentration $\left(\mathrm{mg} \mathrm{L}^{-1}\right)$ & 0.01 & 0.35 \\
& Load $(\mathrm{kg})$ & 0.00 & 0.13 \\
\hline
\end{tabular}

\subsubsection{Comparison of two inflow events 15 years apart}

In order to get a better insight on how the system performance changed over the years, two similar events, almost 15 years apart were compared for their nutrient retention efficiency (Table 6). One event occurred in 2005/06 and another in 2019 (Table 2). Both occurred in autumn and they were a result of similar rain episodes, 162 and $190 \mathrm{~mm}$, respectively. It can be noticed that the 2005/06 event had a much lower water retention in respect to the 2019 one. While before the 2005/06 event the SFCW water level was at $31 \mathrm{~cm}$, the 2019 one started with the empty SFCW. Therefore, such a big difference in effluent volume can be explained by water storage of water inside the system.

Although a comparison of two single events without analysing the overall conditions might not be the best approach, some conclusions can still be drawn. The relatively big dissimilarity in performance of the SFCW during these two events could be connected to the big difference in effluent volume. However, the retention of nitrogen and its 
components during the 2019 event can be considered as high, suggesting that the system efficiency have not deteriorated over the years and that after 2 decades of constant operation it is still functioning properly.

Table 6 - Nutrient balance during two inflow events.

\begin{tabular}{|c|c|c|c|c|c|c|}
\hline & \multicolumn{3}{|c|}{$30^{\text {th }}$ Nov $2005-23^{\text {rd }}$ Jan 2006} & \multicolumn{3}{|c|}{$12^{\text {th }}$ Nov $2019-23^{\text {rd }}$ Dec 2019} \\
\hline & Inflow & Outflow & Retention & Inflow & Outflow & Retention \\
\hline $\begin{array}{l}\text { Water volume } \\
\left(\mathrm{m}^{3}\right)\end{array}$ & 5,220 & 4,139 & - & 6,100 & 1,943 & - \\
\hline $\mathrm{TN}(\mathrm{kg})$ & 110.7 & 60.3 & $46 \%$ & 99.7 & 30.4 & $70 \%$ \\
\hline $\mathrm{NO}_{3}^{-}-\mathrm{N}(\mathrm{kg})$ & 94.7 & 59.3 & $37 \%$ & 78.1 & 23.3 & $70 \%$ \\
\hline $\mathrm{NH}_{4}{ }^{+}-\mathrm{N}(\mathrm{kg})$ & 0.22 & 0.25 & - & 2.32 & 0.19 & $92 \%$ \\
\hline $\mathrm{TP}(\mathrm{kg})$ & 0.09 & 0.21 & - & 0.00 & 0.00 & - \\
\hline
\end{tabular}

\subsection{Soil nutrient and trace elements content}

Figure 4 reports concentration of different elements, including nutrients and trace elements, in the soil layer. A comparison between the 2017 and 2019 results is given. The change in content between two years was minimal and the values were within the same order of magnitude. Therefore, 2 years might not be enough to notice any substantial change up to $60 \mathrm{~cm}$ soil depth and longer time gaps should be considered.

In particular, TOC concentration was 10.0 and $8.8 \mathrm{~g} \mathrm{~kg}^{-1}$ in 2017 and 2019, respectively, and it was similar to the values reported by Maucieri et al. (2014) for a SFCW located near Padua (Italy). TN content was in line with the values found by Passoni et al. (2009), whereas TP concentration was much smaller ( 0.5 vs. $\left.6.5 \mathrm{~g} \mathrm{~kg}^{-1}\right)$. This difference might be a result of a higher TP load or a different soil type. However, both TN and TP content of the SFCW studied here were comparable to the values of the surface soil layer obtained for the same system between 2004 and 2009 (Lavrnić et al. 2018). 

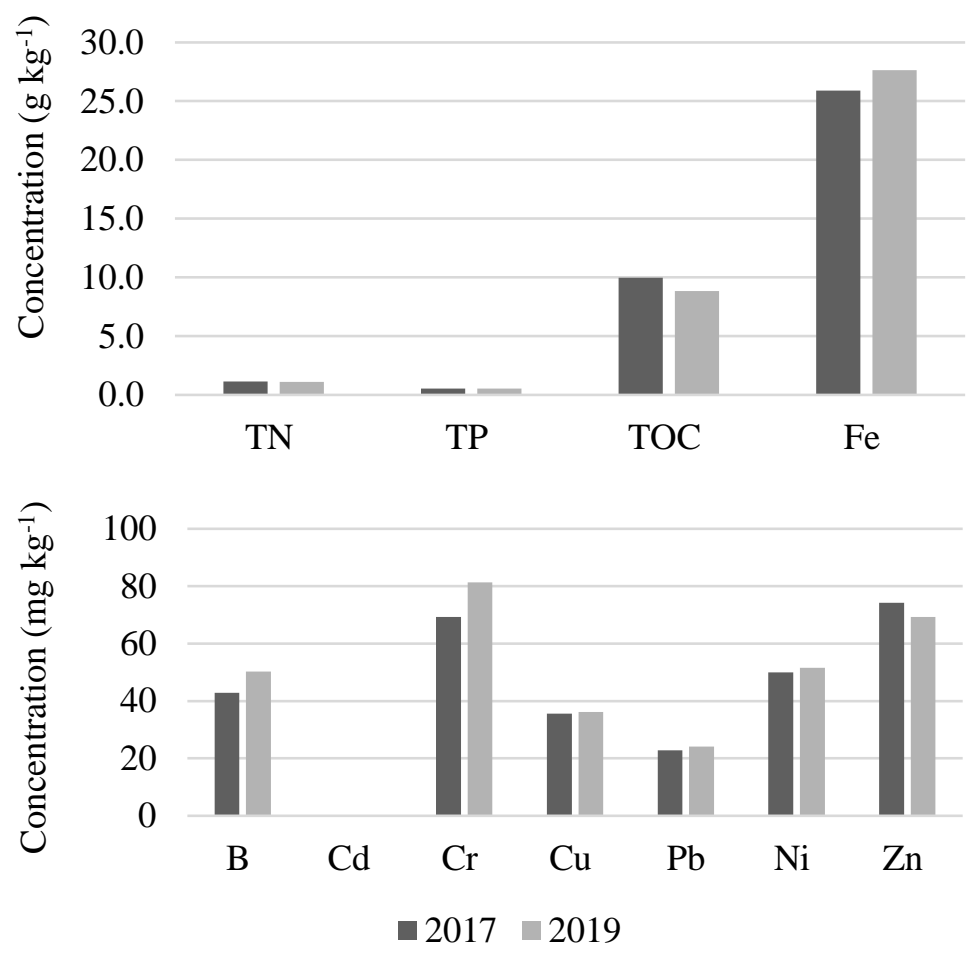

Figure 4 - Concentration of nutrients and trace elements in the SFCW soil.

Iron showed the highest concentration ranging from 25 to $28 \mathrm{~g} \mathrm{~kg}^{-1}$. The average concentration of chrome increased from $69 \mathrm{mg} \mathrm{kg}^{-1}$ in 2017 to $81 \mathrm{mg} \mathrm{kg}^{-1}$ in 2019. Nevertheless, the content of all trace elements in 2019 was comparable to the background data (RER, 2020), and they were within the limits for green areas, private and residential use that were established in 2006 by the Italian law (D.Lgs, 2006).

\subsection{Vegetation development and its nutrient and trace elements accumulation}

Plants can play a positive role on wastewater treatment of CWs, such as by providing a habitat for microbial communities and favourable oxygen transfer (Abou-Elela and Hellal, 2012), uptake of nutrient and heavy metals (Fountoulakis et al. 2017) and facilitating some physical mechanisms (e.g. filtration and sedimentation) (Vymazal, 2011). Also, it is reported that heterogeneity of plant species may provide more ecological 
and aesthetic values due to the presence of structurally and floristically diverse plants patterns (Tanner, 1996). Vegetation used in CWs can be also used for energy purposes due to their high biomass production with considerable heating values (Molari et al. 2014).

Table 6 shows the main results of the plant sampling that was done yearly: before the experimental period in 2017, during it in 2018 and at the end of the experimental period in 2019. Unfortunately, it was not possible to identify all the plant species present in the SFCW, but the three dominant ones were Phragmites australis, Typha latifolia and Carex spp.

Table 6 - Agronomic characteristics of the main plant species in the SFCW.

\begin{tabular}{rrcccc}
\hline & & $\begin{array}{c}\text { Surface } \\
\text { area } \\
\text { covered } \\
(\%)\end{array}$ & $\begin{array}{c}\text { Dry weight } \\
\left(\mathrm{kg} \mathrm{m}^{-2}\right)\end{array}$ & $\begin{array}{c}\text { Above/below } \\
\text { ground biomass } \\
\text { ratio }(\%)\end{array}$ & $\begin{array}{c}\text { Average } \\
\text { height } \\
(\mathrm{cm})\end{array}$ \\
\hline $2017 \quad$ Phragmites australis & 41 & 7.43 & 0.13 & 194 \\
2018 Typha latifolia & 14 & 4.95 & 0.36 & 168 \\
Carex spp. & 45 & 3.69 & 0.21 & 87 \\
& Phragmites australis & 58 & 6.24 & 0.25 & 251 \\
& Typha latifolia & 14 & 9.19 & 0.15 & 231 \\
Carex spp. & 28 & 3.87 & 0.70 & 184 \\
& Phragmites australis & 73 & 9.43 & 0.27 & 266 \\
Typha latifolia & 11 & 5.14 & 0.12 & 125 \\
Carex spp. & 16 & 10.63 & 0.14 & 178 \\
\hline
\end{tabular}

If the surfaces inhabited by the species are compared, it can be seen that Phragmites australis gradually increased its surface, occupying in 2019 more than $70 \%$ of the SFCW area. Phragmites australis mostly spread on the account of Carex spp., while the surface coverage by Typha latifolia was generally constant. Together with increasing its surface area, Phragmites australis also increased its above/below ground biomass ratio and average height. On the other hand, the other two dominant species did not follow the same 
trend. In general, the total biomass of the SFCW was increasing over the years: from 16 $\mathrm{kg} \mathrm{m}^{-2}$ in 2017 , it rose to $19 \mathrm{~kg} \mathrm{~m}^{-2}$ in 2018 and to $25 \mathrm{~kg} \mathrm{~m}^{-2}$ in 2019 . Interestingly, the biomass of Carex spp. had a constant increase, while the other two species showed a certain fluctuation from 2017 to 2019.

Figure 5 displays the concentration of boron, some heavy metals and nutrients contained in plants between 2017 and 2019. In agreement with the results reported by Yadav et al. (2012), the content of $\mathrm{B}, \mathrm{Cu}, \mathrm{Fe}, \mathrm{Ni}, \mathrm{Pb}$ and $\mathrm{Zn}$ in the below-ground biomass was much higher than the observed in the above-ground biomass. Constant decrease of $\mathrm{B}$ and $\mathrm{Fe}$ concentration in the biomass (Figure 5) was probably related to the slight increase of their concentrations in the SFCW soil that observed in the same period (Figure 4).

The total annual accumulation and distribution of nutrients and carbon in plants are shown in Figure 6. Clearly, the below-ground biomass accumulated more TN, TP and TOC than the above-ground one. That feature was in line with the study of Borin and Tocchetto (2007), who emphasized that more TN was retained in the below-ground biomass of Typha latifolia and Phragmites australis because of their transfer from above to belowground organs during the dormant periods. Chanc et al. (2019) found high level of TN and TP stored in above-ground biomass of Juncus effusus and Pontederia cordata, sampled before their senescence, when nutrient transfer still had not taken place.

The uptake rates of TN and TP by above-ground vegetation were in the range of 19.026.3 and 1.6-2.1 $\mathrm{g} \mathrm{m}^{-2}$, respectively. These results were comparable with the ranges of 22.3-41.1 $\mathrm{g} \mathrm{TN} \mathrm{m}^{-2}$ and 1.4-3.8 g TP m² obtained by Vymazal and Dvořáková Březinová (2018b). The TP in the biomass was 14.1, 11.6 and $21.9 \mathrm{~kg}$ in 2017, 2018 and 2019, respectively. The total TN content varied from 113.8 to $208.5 \mathrm{~kg}$ over the three years, 
while the TOC accumulation was in the range of 5,574.1-11,311.9 kg (Figure 6). As a general observation, TP, TN and TOC showed similar values in the 2017-2018 period, followed by a significant increase in 2019. This was consistent with the occupation of SFCW surface by the main plant species, Phragmites australis. In fact, among the others, the species in 2019 reached the maximal extension in term of average height and surface area covered (Table 6).

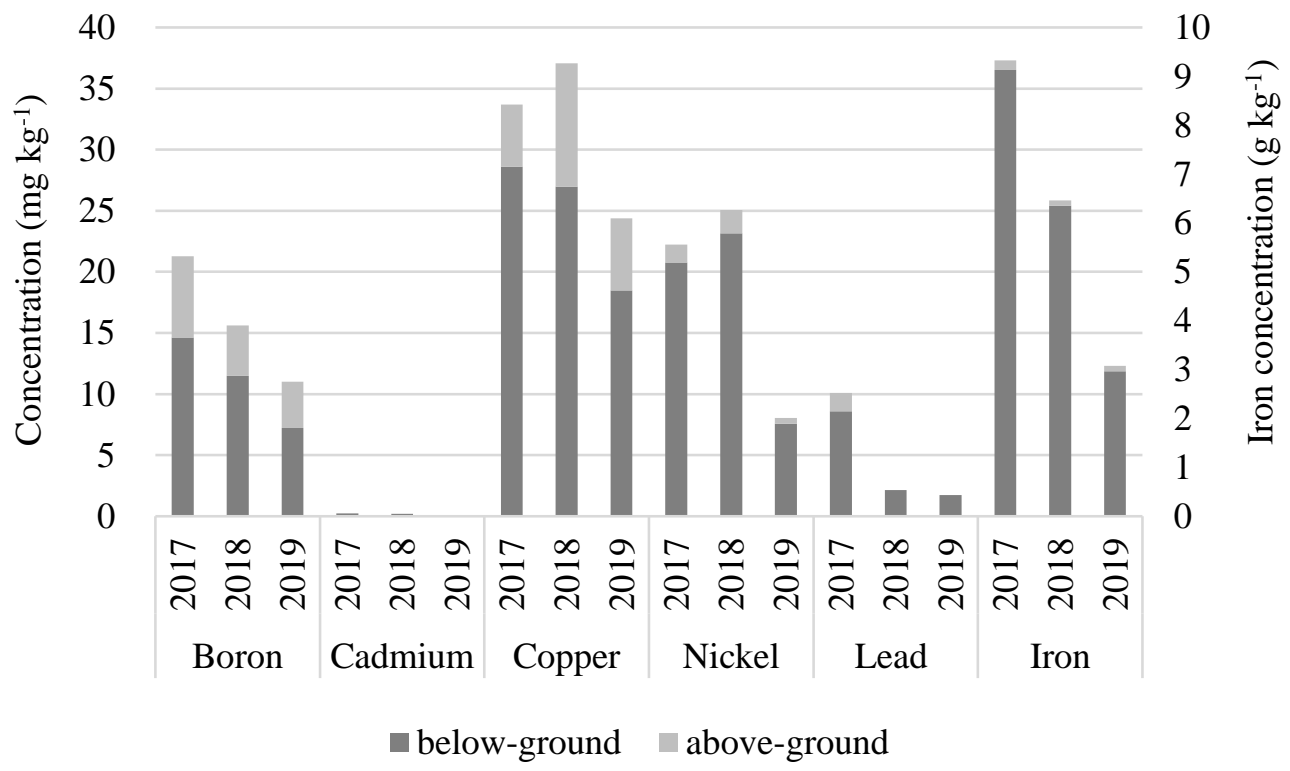

Figure 5 - Distribution of trace elements between above and below-ground biomass.

If compared to the overall balance of the SFCW, the vegetation stored more of these elements than the amount that was removed annually based on the difference between influent and effluent loads (Table 3). However, it should be noted that the above-ground vegetation was not harvested after spring 2017 and therefore it was not possible to do the overall nutrient balance. Although biomass harvesting is recommended to achieve the full nutrient removal potential of vegetation, plant litter can also provide organic matter and suitable attachment surfaces for bacteria inside the system, and thus facilitate removal 
processes, primarily denitrification (Song et al. 2019). An in-depth analysis should be done in order to have a better insight into nutrient circulation inside the SFCW.

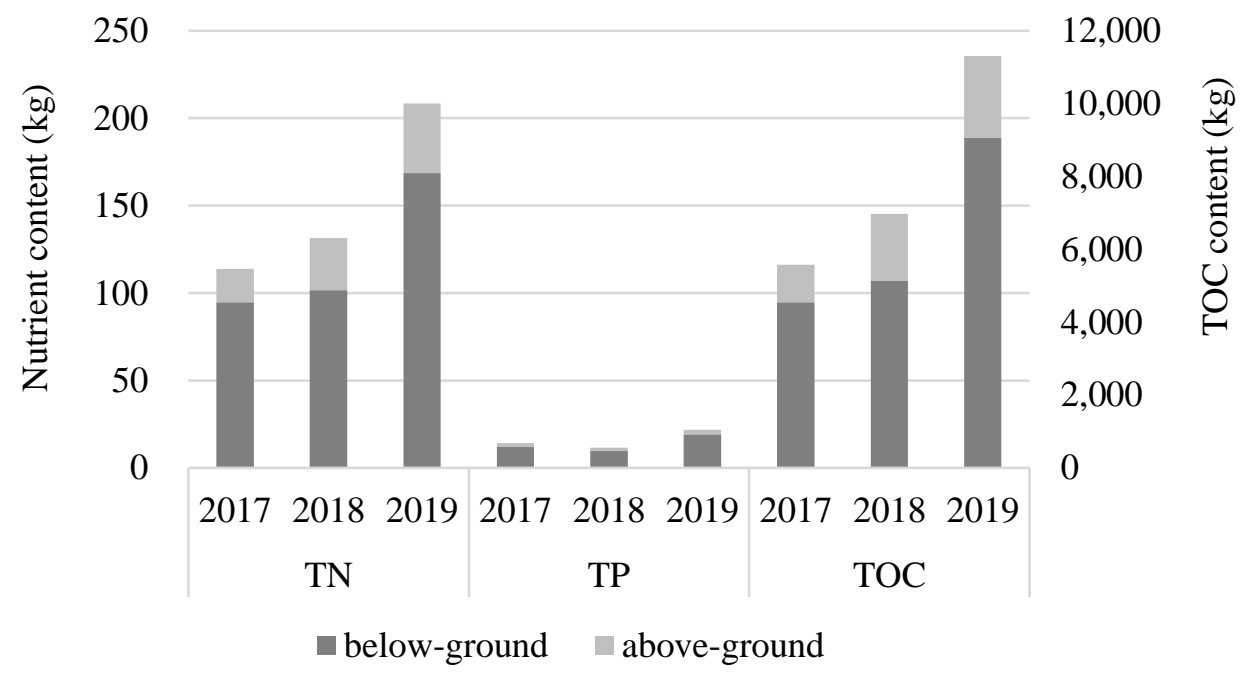

Figure 6 - Total content of total nitrogen (TN), total phosphorus (TP) and total organic carbon (TOC) in below and above-ground biomass.

\section{Conclusions}

Calculation of retention efficiencies based on concentrations might not be the best choice when assessing performance of a non-waterproofed SFCWs. These systems, especially the ones receiving a varying flow like agricultural drainage water, can experience increased water losses and therefore effluent can have a higher concentration of pollutants than influent. To overcome misinterpretation of data, mass load retention can be considered much more appropriate. In order to obtain correct retention efficiencies, it is also important to consider input of nutrients directly through precipitation, since it can represent a sizeable part of the total incoming load. In the SFCW studied, although retention of TP seemed to be poor, additional analysis showed that the result can considerable change when precipitation input is taken into account. 
The soil structure and concentration of nutrients and trace elements did not considerably change over 2 years of monitoring, and, for this reason an assessment of soil over longer time periods is recommended. In addition, the increase of plant total biomass over the years, together with TN, TP and TOC content was indicative of the presence of favourable conditions for the macrophytes development. Further study is needed to close the nutrient balance of the system since it was not possible to estimate the loss of TN and TP through infiltration. That would certainly contribute to the better understanding of dynamics and retention processes occurring inside SFCWs.

Overall, the SFCW studied showed a high efficiency for agricultural drainage water treatment (e.g. up to $82 \%$ TSS retention and up to $78 \%$ for $\mathrm{TN}$ and $\mathrm{NO}_{3}{ }^{-}-\mathrm{N}$ retention), even if it has been in use for two decades. These results indicate that SFCWs can be considered as a cost-effective and long-term ecological engineering solutions for the reduction of non-point source pollution and prevention of eutrophication and deterioration of surface water bodies.

\section{Acknowledgment}

This research was funded by Ministero dell'Istruzione, dell'Università e della Ricerca (MIUR), within the PRIN 2015 programme, through the research project GREEN4WATER (grant number: PRIN2015AKR4HX) available at https://site.unibo.it/green4water. The authors would also like to thank Mr Domenico Solimando for the precious assistance in the field and laboratory and Mr Massimiliano Menghini for taking the pictures of the wetland with a drone. 


\section{References}

Abou-Elela S.I. and Hellal M.S. (2012) Municipal wastewater treatment using vertical flow constructed wetlands planted with Canna, Phragmites and Cyprus. Ecological Engineering 47, 209-213.

Arden S. and Ma X. (2018) Constructed wetlands for greywater recycle and reuse: a review. Science of the Total Environment 630, 587-599.

Bali M., Gueddari M. and Boukchina R. (2010) Treatment of secondary wastewater effluents by infiltration percolation. Desalination 258(1-3), 1-4.

Billy C., Birgand F., Ansart P., Peschard J., Sebilo M. and Tournebize J. (2013) Factors controlling nitrate concentrations in surface waters of an artificially drained agricultural watershed. Landscape Ecology 28, 665-684.

Borin M. and Tocchetto D. (2007) Five years water and nitrogen balance for a constructed surface flow wetland treating agricultural drainage waters. Science of the Total Environment 380, 38-47.

Calheiros C.S.C., Rangel A.O.S.S. and Castro P.M.L. (2009) Treatment of industrial wastewater with two-stage constructed wetlands planted with Typha latifolia and Phragmites australis. Bioresource Technology 100, 3205-3213.

Castaldelli G., Aschonitis V., Vincenzi F., Fano E.A. and Soana E. (2018) The effect of water velocity on nitrate removal in vegetated waterways. Journal of Environmental Management 215, 230-238. 
Chanc L.M.G., Van Brunt S.C., Majsztrik J.C. and White S.A. (2019) Short- and longterm dynamics of nutrient removal in floating treatment wetlands. Water Research 159, 153-163.

Dal Ferro N., Ibrahim H.M.S. and Borin M. (2018) Newly-established free water-surface con-structed wetland to treat agricultural waters in the low-lying Venetian plain: performance on nitrogen and phosphorus removal. Science of the Total Environment 639, $852-859$.

Darwiche-Criado N., Comin F.A., Masip A., Garcia M., Eismann S.G. and Sorando R. (2017) Effects of wetland restoration on nitrate removal in an irrigated agricultural area: The role of in-stream and off-stream wetlands. Ecological Engineering 103, 426-435.

D.Lgs. 152 (Decreto legislativo). Norme in materia ambientale. 2006. (In Italian)

Dou T.T., Troesch S., Petitjean A., Gábor P.T. and Esser D. (2017) Wastewater and rainwater management in urban areas: a role for constructed wetlands. Procedia Environmental Sciences 37, 535-541.

ElZein Z., Abdou A. and ElGawad I.A. (2016) Constructed wetlands as a sustainable wastewater treatment method in communities. Procedia Environmental Sciences 34, 605617.

Fountoulakis M.S., Sabathianakis G., Kritsotakis I., Kabourakis E.M. and Manios T. (2017) Halophytes as vertical-flow constructed wetland vegetation for domestic wastewater treatment. Science of the Total Environment 583, 432-439.

Ghaitidak D.M. and Yadav K.D. (2013) Characteristics and treatment of greywater-a review. Environmental Science and Pollution Research 20, 2795-2809. 
Headley T., Nivala J., Kassa K., Olsson L., Wallace S., Brix H., van Afferden M. and Müller R. (2013) Escherichia coli removal and internal dynamics in subsurface flow ecotechnologies: Effects of design and plants. Ecological Engineering 61, 564-574.

Herrera-Melián J.A., Borreguero-Fabelo A., Araña J., Peñate-Castellano N. and OrtegaMéndez J.A. (2018) Effect of substrate, feeding mode and number of stages on the performance of hybrid constructed wetland systems. Water-Sui 10(1), 39.

Haverstock M., Madani A., Baldé H., Vanderzaag A. and Gordon R. (2017) Performance of an agricultural wetland-reservoir-irrigation management system. Water-Sui 9, 472.

He G., Fang H., Bai S., Liu X., Chen M. and Bai J. (2011) Application of a threedimensional eutrophication model for the Beijing Guanting Reservoir, China. Ecological Modelling 222, 1491-1501.

Hoffman A.R., Polebitski A.S., Penn M.R. and Busch D.L. (2019) Long-term variation in agricultural edge-of-field phosphorus transport during snowmelt, rain, and mixed runoff events. Journal of Environmental Quality 48, 931-940.

Johannesson K.M., Tonderski K.S., Ehde P.M. and Weisner S.E.B. (2017) Temporal phosphorus dynamics affecting retention estimates in agricultural constructed wetlands. Ecological Engineering 103, 436-445.

Kadlec, R.H. and Wallace S.D. (2009) Treatment Wetlands, second edition. Boca Raton, FL: CRC Press.

Kovacic D.A., Twait R.M., Wallace M.P. and Bowling J.M. (2006) Use of created wetlands to improve water quality in the Midwest-Lake Bloomington case study. Ecological Engineering 28(3), 258-270. 
Kynkaanniemi P., Ulen B., Torstensson G.A. and Tonderski K.S. (2013) Phosphorus retention in a newly constructed wetland receiving agricultural tile drainage water. Journal of Environmental Management 42, 596-605.

Lavrnić S. and Mancini M.L. (2016) Can constructed wetlands treat wastewater for reuse in agriculture? Review of guidelines and examples in South Europe. Water Science and Technology 73, 2616-2626.

Lavrnić S., Alagna V., Iovino M., Anconelli S., Solimando D. and Toscano A. (2020) Hydrological and hydraulic behaviour of a surface flow constructed wetland treating agricultural drainage water in northern Italy. Science of the Total Environment 702, 134795.

Lavrnić S., Braschi I., Anconelli S., Blasioli S., Solimando D., Mannini P. and Toscano A. (2018) Long-term monitoring of a surface flow constructed wetland treating agricultural drainage water in Northern Italy. Water 10(5), 644.

Lavrnić S., Cristino S., Zapater-Pereyra M., Vymazal J., Cupido D., Lucchese G., Mancini B. and Mancini M.L. (2019) Effect of earthworms and plants on the efficiency of vertical flow systems treating university wastewater. Environmental Science and Pollution Research 26(10), 10354-10362.

Liu R.B., Zhao Y.Q., Doherty L., Hu Y.S. and Hao X.D. (2015) A review of incorporation of constructed wetland with other treatment processes. Chemical Engineering Journal $279,220-230$.

Maniquiz M.C., Lee S.Y., Choi J.Y., Jeong S.M. and Kim L.H. (2012) Treatment performance of a constructed wetland during storm and non-storm events in Korea. Water Science and Technology 65(1), 119-126. 
Maucieri C., Salvato M., Tamiazzo J. and Borin M. (2014) Biomass production and soil organic carbon accumulation in a free water surface constructed wetland treating agricultural wastewater in North Eastern Italy. Ecological Engineering 70, 422-428.

Mendes L.R.D., Tonderski K., Iversen B.V. and Kjaergaard C. (2018a) Phosphorus retention in surface-flow constructed wetlands targeting agricultural drainage water. Ecological Engineering 120, 94-103.

Mendes L.R.D., Tonderski K. and Kjaergaard C. (2018b) Phosphorus accumulation and stability in sediments of surface-flow constructed wetlands. Geoderma 331, 109-120.

Molari G., Milani M., Toscano A., Borin M., Taglioli G., Villani G., Zema D.A. (2014) Energy characterisation of herbaceous biomasses irrigated with marginal waters. Biomass and Bioenergy 70, 392-399.

Morató J., Codony F., Sánchez O., Pérez L.M., García J. and Mas J. (2014) Key design factors affecting microbial community composition and pathogenic organism removal in horizontal subsurface flow constructed wetlands. Science of the Total Environment 481, 81-89.

Passoni M., Morari F., Salvato M. and Borin M. (2009) Medium-term evolution of soil properties in a constructed surface flow wetland with fluctuating hydroperiod in North Eastern Italy. Desalination 246, 215-225.

Pugliese L., Kusk M., Iversen B.V. and Kjaergaard C. (2020) Internal hydraulics and wind effect in a surface flow constructed wetland receiving agricultural drainage water. Ecological Engineering 144. 
Reinhardt M., Gächter R., Wehrli B. and Müller B. (2005) Phosphorus retention in small constructed wetlands treating agricultural drainage water. Journal of Environmental Quality 34, 1251-1259.

RER (Emilia-Romagna Region) (2020) Carta del Fondo Naturale-Antropico dei Metalli Pesante. Available online: http://ambiente.regione.emiliaromagna.it/geologia/temi/metalli-pesanti/carta-del-fondonaturale antropico-della-pianura-emilianoromagnola-alla-scala1-250-000-2012 (accessed on $16^{\text {th }}$ March 2020). (In Italian)

Rousseau D.P.L., Lesage E., Story A., Vanrolleghem P.A. and De Pauw N. (2008) Constructed wetlands for water reclamation. Desalination 218, 181-189.

Russo N., Pino A., Toscano A., Cirelli G.L., Caggia C., Arioli S., Randazzo C.L. (2019a) Occurrence, diversity, and persistence of antibiotic resistant enterococci in full-scale constructed wetlands treating urban wastewater in Sicily. Bioresource Technology 274, 468-478.

Russo N., Marzo A., Randazzo C., Caggia C., Toscano A., Cirelli G.L. (2019b) Constructed wetlands combined with disinfection systems for removal of urban wastewater contaminants. Science of the Total Environment 656, 558-566.

Song X.J., Ehde P.M. and Weisner S.E.B. (2019) Effects of water depth and phosphorus availability on nitrogen removal in agricultural wetlands. Water-Sui 11(12), 2626.

Steidl J., Kalettka T. and Bauwe A. (2019) Nitrogen retention efficiency of a surface-flow constructed wetland receiving tile drainage water: A case study from north-eastern Germany. Agriculture Ecosystems \& Environment 283, 106577. 
Tanner C.C. (1996) Plants for constructed wetland treatment systems - A comparison of the growth and nutrient uptake of eight emergent species. Ecological Engineering 7, 5983.

Tanner C.C. and Kadlec R.H. (2013) Influence of hydrological regime on wetland attenuation of diffuse agricultural nitrate losses. Ecological Engineering 56, 79-88.

Tolomio M., Dal Ferro N. and Borin M. (2019) Multi-year N and P removal of a 10-yearold surface flow constructed wetland treating agricultural drainage waters. AgronomyBasel 9(4), 170.

Toscano A., Hellio C., Marzo A., Milani M., Lebret K., Cirelli G.L., Langergraber G. (2013) Removal efficiency of a constructed wetland combined with ultrasound and UV devices for wastewater reuse in agriculture. Environmental Technology 34(15), 2327 2336.

Tournebize J., Chaumont C. and Mander Ü. (2017) Implications for constructed wetlands to mitigate nitrate and pesticide pollution in agricultural drained watersheds. Ecological Engineering 103, 415-425.

Ulén B., Geranmayeh P., Blomberg M. and Bieroza M. (2019) Seasonal variation in nutrient retention in a free water surface constructed wetland monitored with flowproportional sampling and optical sensors. Ecological Engineering 139, 105588.

Vant W. and Gibbs M. (2006) Nitrogen and phosphorus in Taupo rainfall. Environment Waikato Technical Report 2006/46. Environment Waikato, Hamilton.

Vymazal J. (2007). Removal of nutrients in various types of constructed wetlands. Science of the Total Environment 380, 48-65. 
Vymazal J. (2011) Plants used in constructed wetlands with horizontal subsurface flow: a review. Hydrobiologia 674, 133-156.

Vymazal J. (2017) The use of constructed wetlands for nitrogen removal from agricultural drainage: a review. Scientia Agriculturae Bohemica 48(2), 82-91.

Vymazal J. and Dvořáková Březinová T. (2018a) Removal of nutrients, organics and suspended solids in vegetated agricultural drainage ditch. Ecological Engineering 118, 97-103.

Vymazal J. and Dvořáková Březinová T. (2018b) Treatment of a small stream impacted by agricultural drainage in a semi-constructed wetland. Science of the Total Environment $643,52-62$.

Woltemade C.J. (2000) Ability of restored wetlands to reduce nitrogen and phosphorus concentrations in agricultural drainage water. Journal of Soil and Water Conservation 55, 303-309.

Yadav A.K., Abbassi R., Kumar N., Satya S., Sreekrishnan T.R. and Mishra B.K. (2012) The removal of heavy metals in wetland microcosms: Effects of bed depth, plant species, and metal mobility. Chemical Engineering Journal 211-212, 501-507. 